\title{
Comparative Studies of New Complexes Synthesized by Chemical and Tribochemical Reactions Derived from Malonic Acid Dihydrazide (L; MAD) with $\mathrm{Cu}^{2+}$ and $\mathrm{Co}^{2+}$ Salts
}

\author{
Sawsan Mohamed Al-Ashqar \\ Department of Chemistry, Faculty of Applied Sciences, Umm Al-Qura University, Makkah, KSA \\ Email: d.sawsan94@hotmail.com
}

How to cite this paper: Al-Ashqar, S.M. (2018) Comparative Studies of New Complexes Synthesized by Chemical and Tribochemical Reactions Derived from Malonic Acid Dihydrazide (L; MAD) with $\mathrm{Cu}^{2+}$ and $\mathrm{Co}^{2+}$ Salts. Open Journal of Inorganic Chemistry, 8, 28-42.

https://doi.org/10.4236/ojic.2018.81003

Received: October 25, 2017

Accepted: January 26, 2018

Published: January 29, 2018

Copyright $\odot 2018$ by author and Scientific Research Publishing Inc. This work is licensed under the Creative Commons Attribution International License (CC BY 4.0).

http://creativecommons.org/licenses/by/4.0/

\section{Open Access}

\begin{abstract}
The reaction of $\mathrm{L}$ (MAD) with $\mathrm{Cu}^{2+}$ and $\mathrm{Co}^{2+}$ chlorides affords new metal complexes. The isolated solid complexes were synthesized by two different techniques i.e., chemical and tribochemical methods. Four new complexes were synthesized by direct chemical reactions of $\mathrm{MCl}_{2}\left(\mathrm{M}=\mathrm{Co}^{2+}\right.$ and $\left.\mathrm{Cu}^{2+}\right)$ with MAD in absolute EtOH. The isolated solid complexes were used as starting compounds to synthesize another four new complexes using tribochemical technique by grinding the previous complexes in the solid state with excess KI in agate mortar. The results of the isolated complexes indicate the substitution of the chloride by iodide ions during grinding and extraction of the complexes by a mixture of solvents $(\mathrm{EtOH}+\mathrm{MeOH})$. Also, the results suggest that no reduction of $\mathrm{Cu}^{2+}$ or oxidation of $\mathrm{Co}^{2+}$ complexes is observed. The IR spectra of the complexes suggest that $\mathrm{L}$ acts in a bidentate manner. Moreover, the results of electronic spectra and magnetic measurements for the chloride and iodide complexes suggest distorted-octahedral and/or tetrahedral for $\mathrm{Cu}^{2+}$ and high-spin octahedral and/or tetrahedral structures around the $\mathrm{Co}^{2+}$ ion, respectively.
\end{abstract}

\section{Keywords}

Tribochemical Reactions, MAD Complexes, Spectral and Magnetic Studies, $\mathrm{Cu}^{2+}$ and $\mathrm{Co}^{2+}$ Complexes, Green Chemistry

\section{Introduction}

Malonic acid dihydrazide (MDH; L) is a vital class of ligands in coordination chemistry and finds extensive applications in different fields [1]. Dihydrazide 
derivatives are polydentate ligands coordinating in neutral forms [2]. The applications of metal complexes in various fields like anti-inflammatory and analgesic have been extensively examined [3]. The hydrazide moiety $\left(-\mathrm{N}_{2} \mathrm{H}_{4}\right)$ possesses a potential therapeutic effect and plays an important role in medicine [4] [5] [6]. Earlier work illustrated that some drugs show increased activity when administered as metal chelates rather in the form of original organic compounds [7] [8]. These complexes play an important role in bioinorganic chemistry and redox enzyme systems [9] [10] [11]. The study of structural and binding features of various metal complexes plays an important role in understanding of the biological process. Redox properties of a drug can give insight into its metabolic or pharmaceutical activity [12] [13] [14]. Literature survey indicates that electrochemical studies have been manipulated to predict the behavior of ligand and its metal complexes in biochemistry and medicine [15]. In recent years, an increasing number of complexes derived from dihydrazides have been investigated [16]. Also, an increasing number of transition metal complexes of dihydrazides have been studied in details [17]. However, no attempt appears to have been made to monitor the tribochemical reactions derived from dihydrazides. The aim of present work is to study the synthesis of novel $\mathrm{Cu}^{2+}$ and $\mathrm{Co}^{2+}$ complexes derived from L (MAH) by both chemical and tribochemical reactions and the isolated solid complexes were characterized by elemental analyses, spectral (IR, ${ }^{1} \mathrm{H}-\mathrm{NMR}$ and UV-vis.) and magnetic measurements. The goal of synthesis of complexes by tribochemical is to study the role of KI on substitution and the oxidation and/or reduction of the metal ions. Also, this method gives high yield and is considered as a cheap and new method for synthesis of new types of complexes.

\section{Experimental}

All the chemicals (salts and solvents) were purchased from Aldrcih and used without purification. Malonic acid dihydrazide (MAH, L) was synthesized by refluxing equivalent amounts of diethyl malonate $(15.2 \mathrm{ml})$ in $\mathrm{EtOH}$ and hydrazine hydrate $(6.2 \mathrm{ml})$ on water bath for $4 \mathrm{hrs}$. The white product (m.p.; $152^{\circ} \mathrm{C}$ $156^{\circ} \mathrm{C}$; yield: $90 \%$ ) was obtained by cooling and the product was characterized by chemical and spectral methods. The ligand ( $\mathrm{MAH}, \mathrm{L})$ was crystallized from absolute EtOH.

\subsection{Preparation of Metal Complexes}

\subsubsection{Preparation of $\mathrm{Cu}^{2+}$ and $\mathrm{Co}^{2+}$ Complexes by Chemical Method}

Four solid complexes derived from the reaction of $\mathrm{CuCl}_{2}$ and $\mathrm{CoCl}_{2}$ dissolved in $\mathrm{EtOH}\left(25 \mathrm{ml}\right.$ with $\mathrm{L}$ in $50 \mathrm{ml} \mathrm{EtOH}$ with the general formulae, $\left[\mathrm{Cu}(\mathrm{L}) \mathrm{Cl}_{2}\right]$, $\left[\mathrm{Co}_{2}(\mathrm{~L})_{2}\left(\mathrm{H}_{2} \mathrm{O}\right) \mathrm{Cl}\right] \mathrm{Cl},\left[\mathrm{Cu}(\mathrm{L})_{3}\right] \mathrm{Cl}_{3} \cdot \frac{1}{2} \mathrm{EtOH}$ and $\left[\mathrm{Co}(\mathrm{L})_{3}\right] \mathrm{Cl}_{2}$, were synthesized and characterized. The reaction mixtures were refluxed on a water bath for $1 \mathrm{hr}$. The complexes were filtered off, washed several times with absolute EtOH followed by dry diethyl ether and finally dried in a vacuum desiccator over anhydrous $\mathrm{P}_{4} \mathrm{O}_{10}$. 
$\left[\mathrm{Cu}(\mathrm{L}) \mathrm{Cl}_{2}\right]$ is olive-green in color. Anal. Calcd: for $\mathrm{C}_{3} \mathrm{H}_{8} \mathrm{CuN}_{4} \mathrm{O}_{2} \mathrm{Cl}_{2}$ (266.6): C, 13.5; $\mathrm{H}, 3.0 ; \mathrm{N}, 21.0 ; \mathrm{Cu}, 23.8 ; \mathrm{Cl}, 12.9 \%$. Found: $\mathrm{C}, 12.9 ; \mathrm{H}, 2.8 ; \mathrm{N}, 20.6 ; \mathrm{Cu}$, 23.4; Cl, 12.2\%; Yield 85\%; green powder; m.p.; $168^{\circ} \mathrm{C}$; Yield: $90 \% ; \Lambda_{\mathrm{m}}^{+}$ (DMSO): $9 \mathrm{ohm}^{-1} \cdot \mathrm{cm}^{2} \cdot \mathrm{mol}^{-1}$ and $\mu_{\text {eff }}(2.0 \mathrm{BM})$.

$\left[\mathrm{Co}(\mathrm{L})_{2}\left(\mathrm{H}_{2} \mathrm{O}\right) \mathrm{Cl}\right] \mathrm{Cl}$ is pink in color. Anal. Calcd: for $\mathrm{C}_{6} \mathrm{H}_{18} \mathrm{Co}_{2} \mathrm{~N}_{8} \mathrm{O}_{5} \mathrm{Cl}_{2}$ (412.118): C, 17.5; H, 4.4; N, 27.2; Co, 14.3; Cl, 17.2\%. Found: C, 17.2; H, 4.1; N, 27.1; Co, 14.3; Cl, 17.2\%.; m.p.; $218^{\circ} \mathrm{C}$; Yield: $86 \% ; \Lambda_{\mathrm{m}}^{+}$(DMSO): 55 $\mathrm{ohm}^{-1} \cdot \mathrm{cm}^{2} \cdot \mathrm{mol}^{-1}$ and $\mu_{\text {eff }}(5.2 \mathrm{BM})$.

$\left[\mathrm{Cu}(\mathrm{L})_{3}\right] \mathrm{Cl}_{2} \cdot \frac{1}{12} \mathrm{EtOH}$ is brown in color. Anal. Calcd: for $\mathrm{C}_{10} \mathrm{H}_{27} \mathrm{CuN}_{12} \mathrm{O}_{6} \mathrm{Cl}_{2}$ (553.868): C, 21.7; H, 4.9; N, 30.3; Cu, 11.5; Cl, 12.8\%. Found: C, 21.6; H, 4.8; N, 30.8; Cu, 11.1; $\mathrm{Cl}, 12.6 \%$; m.p.; $254^{\circ} \mathrm{C}$; Yield: $90 \%$; $\Lambda_{\mathrm{m}}^{+}$(DMSO): 70 $\mathrm{ohm}^{-1} \cdot \mathrm{cm}^{2} \cdot \mathrm{mol}^{-1}$ and $\mu_{\text {eff }}(2.0 \mathrm{BM})$.

[Co(L) $\left.)_{3}\right] \mathrm{Cl}_{2}$ is violet in color. Anal. Calcd: for $\mathrm{C}_{10} \mathrm{H}_{27} \mathrm{CoN}_{12} \mathrm{O}_{6} \mathrm{Cl}_{2}$ (526.223): C, 20.5; H, 4.6; N, 31.9; Co, 11.2; Cl, 13.5\%. Found: C, 20.4; H, 5.0; N, 31.2; Co, 10.9; Cl, 13.3\%.; m.p.; $184^{\circ} \mathrm{C}$; Yield: $80 \%$; $\Lambda_{\mathrm{m}}^{+}$(DMSO): $75 \mathrm{ohm}^{-1} \cdot \mathrm{cm}^{2} \cdot \mathrm{mol}^{-1}$ and $\mu_{\text {eff }}(4.9 \mathrm{BM})$.

\subsubsection{Preparation of $\mathrm{Cu}^{2+}$ and $\mathrm{Co}^{2+}$ Complexes by Tribochemical Reactions}

$\mathrm{The}^{2+}$ and $\mathrm{Co}^{2+}$ complexes $(0.5 \mathrm{~g})$ synthesized from the previous method were grinded with $\mathrm{KI}(6 \mathrm{~g})$ for $2 \mathrm{hrs}$ until the color of the original complex is changed. A mixture of $\mathrm{MeOH}(80 \mathrm{ml})$ and $\mathrm{EtOH}(20 \mathrm{ml})$ was then added and the solution was refluxed for $2 \mathrm{hrs}$ and then left overnight. The isolated complexes with the general formulae; $\left[\mathrm{Cu}(\mathrm{L}) \mathrm{I}_{2}\right] \cdot 2 \mathrm{H}_{2} \mathrm{O}, \quad\left[\mathrm{Co}(\mathrm{L})_{2} \mathrm{I}_{2}\right] \cdot 2 \mathrm{H}_{2} \mathrm{O},\left[\mathrm{Co}(\mathrm{L})_{3}\right] \mathrm{I}_{2} \cdot 1 / 2 \mathrm{EtOH} \cdot 2 \mathrm{H}_{2} \mathrm{O}$ and $\left[\mathrm{Cu}(\mathrm{L})_{3}\right] \mathrm{I}_{2}$; were filtered off, washed with $100 \mathrm{ml}$ of a mixture of EtOH and $\mathrm{H}_{2} \mathrm{O}(1: 1)$ and finally dried in an oven at $80^{\circ} \mathrm{C}$; Yield: $78 \%-88 \%$.

$\left[\mathrm{Cu}(\mathrm{L}) \mathrm{I}_{2}\right] \cdot 2 \mathrm{H}_{2} \mathrm{O}$ is pale yellow in color. Anal. Calcd: for $\mathrm{C}_{3} \mathrm{H}_{12} \mathrm{CuN}_{4} \mathrm{O}_{3} \mathrm{I}_{2}$ (485.509): C, 7.4; H, 2.5; N, 11.5; Cu, 13.1; I, 52.3\%. Found: C, 6.7; H, 1.9; N, 11.1; $\mathrm{Cu}, 13.0$; I, 52.1\%.; m.p.; $210^{\circ} \mathrm{C}$; Yield: $78 \% ; \Lambda_{\mathrm{m}}^{+}$(DMSO): $8 \mathrm{ohm}{ }^{-1} \cdot \mathrm{cm}^{2} \cdot \mathrm{mol}^{-1}$ and $\mu_{\text {eff }}(1.8 \mathrm{BM})$.

[Co(L) $\left.\left(\mathrm{H}_{2} \mathrm{O}\right)_{2} \mathrm{I}_{2}\right]$ is simon in color. Anal. Calcd: for $\mathrm{C}_{6} \mathrm{H}_{20} \mathrm{CoN}_{4} \mathrm{O}_{4} \mathrm{I}_{2}$ (613.028): C, 11.8; H, 3.3; N, 18.3; Co, 9.6; I, 41.4\%. Found: C, 11.8; H, 2.8; N, 17.7; Co, 9.3; I, $40.9 \%$; m.p.; $196^{\circ} \mathrm{C}$; Yield: $82 \% ; \Lambda_{\mathrm{m}}^{+}$(DMSO): $5 \mathrm{ohm}^{-1} \cdot \mathrm{cm}^{2} \cdot \mathrm{mol}^{-1}$ and $\mu_{\text {eff }}(4.9$ $\mathrm{BM})$.

[Co(L) $\left.)_{3}\right] \mathrm{I}_{2} \cdot 1 / 2 \mathrm{EtOH} \cdot 2 \mathrm{H}_{2} \mathrm{O}$ is buff in color. Anal. Calcd: for $\mathrm{C}_{10} \mathrm{H}_{27} \mathrm{CoN}_{12} \mathrm{O}_{6} \mathrm{I}_{2}$ (768.192): C, 15.6; H, 4.1; N, 21.9; Co, 7.7; I, 33.0\%. Found: C, 15.4; H, 3.7; N, 21.2; Co, 7.2; I, 32.4\%.; m.p.; $238^{\circ} \mathrm{C}$; Yield: $88 \%$; $\Lambda_{\mathrm{m}}^{+}$(DMSO): $66 \mathrm{ohm}{ }^{-1} \cdot \mathrm{cm}^{2} \cdot \mathrm{mol}^{-1}$ and $\mu_{\text {eff }}(5.0 \mathrm{BM})$.

$\left[\mathrm{Cu}(\mathrm{L})_{3}\right] \mathrm{I}_{2}$ is brown in color. Anal. Calcd: for $\mathrm{C}_{9} \mathrm{H}_{24} \mathrm{CuN}_{12} \mathrm{O}_{6} \mathrm{I}_{2}$ (713.278): C, 15.1; H, 3.4; N, 23.6; Cu, 8.9; I, 35.6\%. Found: C, 14.7; H, 2.8; N, 22.8; Cu, 8.1; I, 35.1\%.; m.p.; $245^{\circ} \mathrm{C}$; Yield: $75 \% ; \Lambda_{\mathrm{m}}^{+}$(DMSO): $59 \mathrm{ohm}^{-1} \cdot \mathrm{cm}^{2} \cdot \mathrm{mol}^{-1}$ and $\mu_{\text {eff }}(1.78$ $\mathrm{BM})$.

\subsection{Physical Measurements}

Elemental analyses contents $(\mathrm{C}, \mathrm{H}$ and $\mathrm{N})$ were determined at the Microanalyti- 
cal Unit, Center of King Fahd Institute at Jeddah, Saudi Arabia. Copper and cobalt contents were determined by complexometric titration in the presence of Xylenol orange as an indicator [18]. Molar conductivities measurements were carried out using Tacussel model CD 75. The chloride and iodide contents were determined as $\mathrm{AgCl}$ or AgI [18]. The IR spectra in the $400-4000 \mathrm{~cm}^{-1}$ range were recorded in $\mathrm{KBr}$ on a Mattson 5000 FTIR Spectrometer. The electronic spectra of the $\mathrm{Cu}^{2+}$ and $\mathrm{Co}^{2+}$ complexes were recorded in Nujol mull in the range (200 - $900 \mathrm{~nm}$ ) using Unicam spectrometer model UV2. L was recorded on ${ }^{1} \mathrm{H}-\mathrm{NMR}$ Spectrometer $(400 \mathrm{MHz})$ in $\mathrm{d}_{6}$-DMSO at Mansoura University at Mansoura. Magnetic moments were determined using a Sherwood balance at room temperature $\left(25^{\circ} \mathrm{C}\right)$ with $\mathrm{Hg}\left[\mathrm{Co}(\mathrm{NSC})_{4}\right]$ as a calibrate. The diamagnetic corrections for $\mathrm{L}$ and its metal atoms were computed using Pascal's constants [19]. The corrected values were calculated according to the following equation:

$$
\mathrm{X}_{\text {dia. }}(\text { molar })=\sum n_{A} \chi_{A}+\sum \lambda
$$

where

$$
\begin{aligned}
& \chi_{A}=\text { gram atomic susceptibility of atom } A . \\
& n_{A}=\text { is the number of atom } A \text { in the compound. } \\
& \lambda=\text { constitutive for certain bond types. }
\end{aligned}
$$

\section{Results and Discussion}

\subsection{Physical Properties and Elemental Analyses}

All the isolated metal complexes are colored, stable against light and air for two years. Also, the complexes are insoluble in most common organic solvents but easily soluble in DMF and DMSO. The molar conductivities for all the iodide complexes are non-conducting except the two complexes with the general formulae, $\left[\mathrm{Cu}(\mathrm{L})_{3}\right] \mathrm{I}_{2}$ and $\left[\mathrm{Co}(\mathrm{L})_{3}\right] \mathrm{I}_{2} \cdot 1 / 2 \mathrm{EtOH} \cdot 2 \mathrm{H}_{2} \mathrm{O}$, which are conducting and have values 75 and $88 \Omega^{-1} \cdot \mathrm{cm}^{2} \cdot \mathrm{mol}^{-1}$ in DMSO, respectively. On the other hand, the molar conductance of the chloride complexes in DMSO falls in the $55-75$ $\Omega^{-1} \cdot \mathrm{cm}^{2} \cdot \mathrm{mol}^{-1}$ indicating 1:1 and 1:2 electrolytes, respectively. The low value (9 $\Omega^{-1} \cdot \mathrm{cm}^{2} \cdot \mathrm{mol}^{-1}$ ) for $\left[\mathrm{Cu}(\mathrm{L}) \mathrm{Cl}_{2}\right]$ indicates that the complex is non-electrolytic [20]. Moreover, the results show that the metal complexes have comparatively low melting points $\left(168^{\circ} \mathrm{C}-254^{\circ} \mathrm{C}\right)$ suggesting the weakness of the bond between the metal ions and $\mathrm{L}$. The structure of $\mathrm{L}$ is represented as shown in Figure 1.

\subsection{Infrared Spectra}

The IR spectrum of $\mathrm{L}$ in $\mathrm{KBr}$ (Figure S1) shows several bands at 3315, 3296 and $3131 \mathrm{~cm}^{-1}$ assigned to $v_{\text {as }}\left(\mathrm{NH}_{2}\right), v_{s}\left(\mathrm{NH}_{2}\right)$ and $v(\mathrm{NH})$ vibrations, respectively. The observation of broad weak bands in the $1940-1800$ and $2755-2500 \mathrm{~cm}^{-1}$ region suggests the presence of intra-molecular hydrogen bonding of the types O-H......N and/or N-H.... [21] [22]. The bands observed at 1705 sh, 1635 sh and $1539 \mathrm{~s} \mathrm{~cm}^{-1}$ are assigned to $v(\mathrm{C}=\mathrm{O}), v\left(\mathrm{NH}_{2}\right)$ and $v(\mathrm{~N}-\mathrm{C}-\mathrm{O})$ vibrations, respectively. The observation of the former two bands as shoulder bands suggests these 

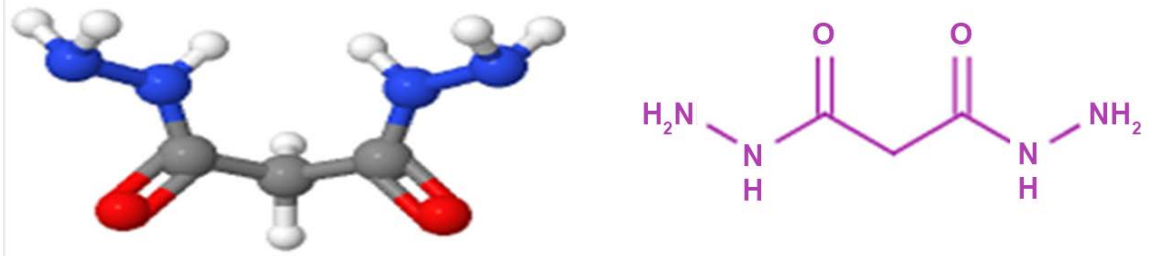

Figure 1. Malonohydrazide (L; MDH).

groups are taken part in hydrogen bonding. The results suggest that the first type of the hydrogen bonding $(\mathrm{O}-\mathrm{H} \ldots \mathrm{N})$ is more likely occurred. All these foundations suggest that $\mathrm{L}(\mathrm{MDH})$ can be represented in Figure 2 .

The mode of bonding was determined by comparing the IR spectra of $\mathrm{L}$ with its complexes $\left(\mathrm{Cu}^{2+}\right.$ and $\left.\mathrm{Co}^{2+}\right)$. The IR spectra of the complexes obtained by chemical method with the general formulae, $\left[\mathrm{Cu}(\mathrm{L}) \mathrm{Cl}_{2}\right]$ (Figure S2), $\left[\mathrm{Co}(\mathrm{L})_{2}\left(\mathrm{H}_{2} \mathrm{O}\right) \mathrm{Cl}\right] \mathrm{Cl}$ (Figure S3), $\left[\mathrm{Cu}(\mathrm{L})_{3}\right] \mathrm{Cl}_{2} \cdot \frac{1}{2} \mathrm{EtOH}$ (Figure S4) and $\left[\mathrm{Co}(\mathrm{L})_{3}\right] \mathrm{Cl}_{2}$ (Figure S5) indicate that the $\mathrm{L}$ behaves in a bidentate manner and coordinates via the two carbonyl groups forming six-membered ring around the metal ions. The negative shifts of these two bands to lower wavenumbers show the involvement of both these groups in bonding. The most important assignments IR bands for $\mathbf{L}$ and its metal complexes are listed in Table 1. Also, the ligand behaves in bidentate manner via the carbonyl oxygen $(\mathrm{CO})$ and the amino $\left(\mathrm{NH}_{2}\right)$ groups in case of the complexes with the general formula, $\left[\mathrm{M}(\mathrm{L})_{3}\right] \mathrm{I}_{2} \cdot \mathrm{XS}(\mathrm{M}=$ $\mathrm{Cu}^{2+}, \mathrm{Co}^{2+}$ and $\mathrm{XS}=$ zero in case of $\mathrm{Cu}^{2+}$ while $\mathrm{XS}=1 / 2 \mathrm{EtOH} \cdot 2 \mathrm{H}_{2} \mathrm{O}$ in case of $\left.\mathrm{Co}^{2+}\right)$.

\subsection{H-NMR Spectra}

The ${ }^{1} \mathrm{H}$-NMR spectrum of $\mathrm{L}$ in $\mathrm{d}_{6}$-DMSO displays four signals at $10.3,9.9,9.3$ and 3.9, relative to TMS (Figure 3). These signals are assigned to $\mathrm{NH}_{2}$ (hydrogen-bonded), $\mathrm{NH}_{2}$ (free), $\mathrm{NH}$ (free) and $\mathrm{CH}_{2}$ protons, respectively. The results are taken as strong evidence for the existence of hydrogen bonding between $\mathrm{CO}$ and $\mathrm{NH}_{2}$ groups and coincide with the results of IR spectra. The former three signals disappear on adding $\mathrm{D}_{2} \mathrm{O}$ as shown in Figure S6.

\subsection{Electronic Spectra and Magnetic Data}

The $\mathrm{Cu}^{2+}$ and $\mathrm{Co}^{2+}$ complexes with the general formulae, $\left[\mathrm{Cu}(\mathrm{L}) \mathrm{Cl}_{2}\right]$ (Figure S7), $\left[\mathrm{Co}(\mathrm{L})_{2}\left(\mathrm{H}_{2} \mathrm{O}\right) \mathrm{Cl}\right] \mathrm{Cl}$ (Figure S8), $\left[\mathrm{Cu}(\mathrm{L})_{3}\right] \mathrm{Cl}_{2} \cdot \frac{1}{2} \mathrm{EtOH}$ (Figure S9) and $\left[\mathrm{Co}(\mathrm{L})_{3}\right] \mathrm{Cl}_{2}$ (Figure S10), were carried out in Nujol mull. The spectrum of the $\mathrm{Cu}^{2+}$ complex, $\left[\mathrm{Cu}(\mathrm{L})_{3}\right] \mathrm{Cl}_{2} \cdot{ }^{1 / 2} \mathrm{EtOH}$, shows a band at $14368 \mathrm{~cm}^{-1}$ attributed to ${ }^{2} \mathrm{E}_{\mathrm{g}} \rightarrow{ }^{2} \mathrm{~T}_{2 \mathrm{~g}}$ transition [19] in a distorted-octahedral geometry around the $\mathrm{Cu}^{2+}$ ion. The value of magnetic moment is $2.0 \mathrm{BM}$ is taken as additional evidence for the existence of distorted-octahedral geometry around the $\mathrm{Cu}^{2+}$ ion. On the other hand, the value of magnetic moment of the $\mathrm{Co}^{2+}$ complexes, $\left[\mathrm{Co}(\mathrm{L})_{2} \mathrm{Cl}_{2}\right] \mathrm{Cl}(5.2 \mathrm{BM})$ and $\left[\mathrm{Co}(\mathrm{L})_{3}\right] \mathrm{Cl}_{2}(4.9 \mathrm{BM})$ suggests the paramagnetic nature of the two complexes and the existence of $\mathrm{d}^{7}$-configuration around the $\mathrm{Co}^{2+}$ ion. Also, the data suggest that 


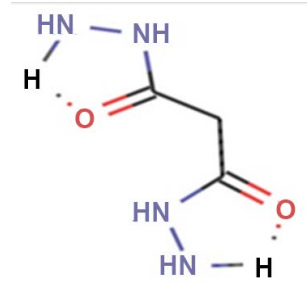

Figure 2. The hydrogen bond in $\mathrm{MDH}$.

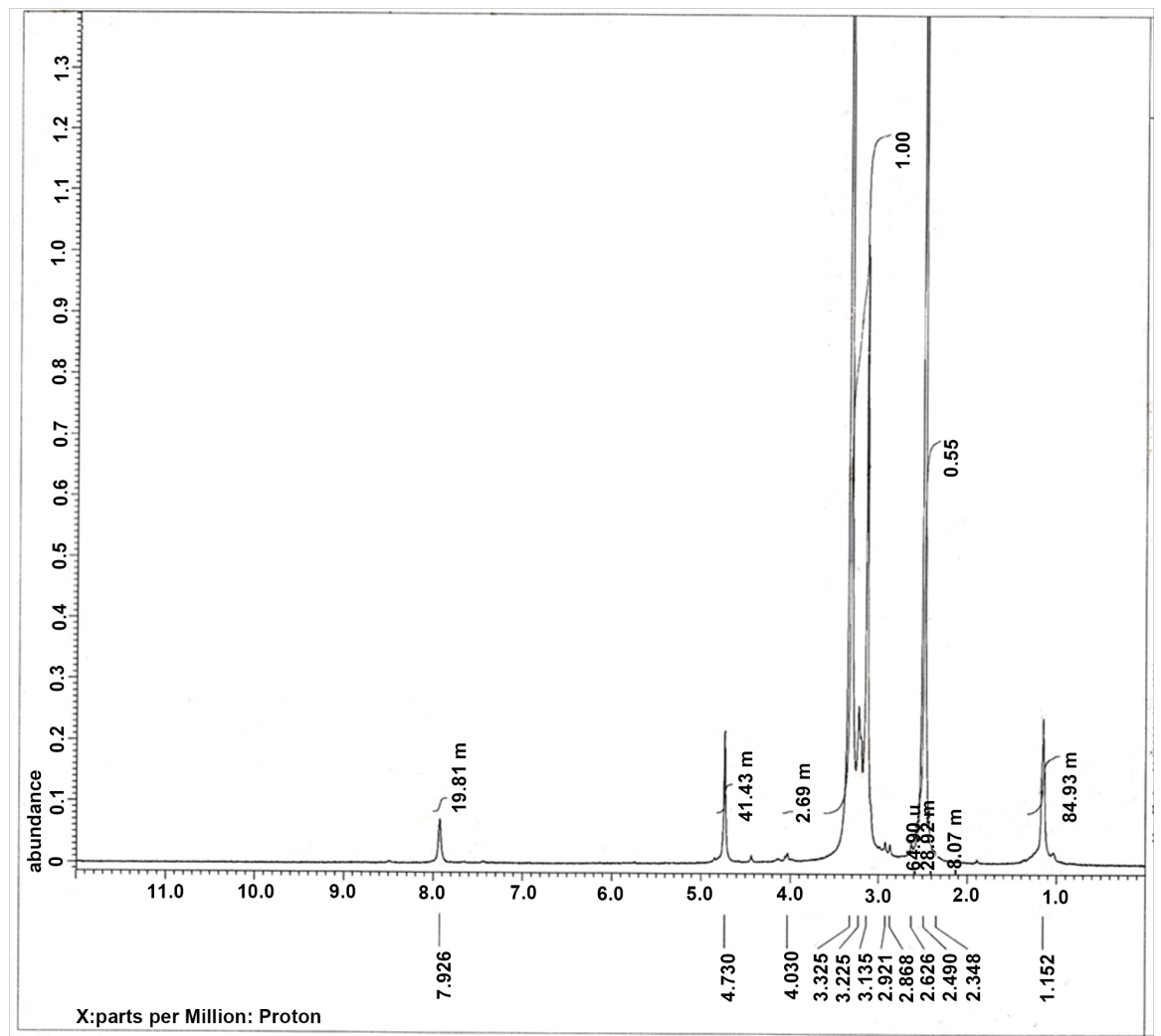

Figure 3. ${ }^{1} \mathrm{H}-\mathrm{NMR}$ spectrum of $\mathrm{L}$ in $\mathrm{d}_{6}$-DMSO.

Table 1. The most important IR bands of MDH and its complexes.

\begin{tabular}{|c|c|c|c|c|c|c|c|}
\hline Compound & $v(\mathrm{OH})$ solvent & $v_{\mathrm{as}}\left(\mathrm{NH}_{2}\right)$ & vs $\left(\mathrm{NH}_{2}\right)$ & $v(\mathrm{NH})$ & $v(\mathrm{CO})$ & $v(\mathrm{~N}-\mathrm{C}-\mathrm{O})$ & $v(\mathrm{M}-\mathrm{N})$ \\
\hline $\mathrm{L}^{1}, \mathrm{MDH}$ & - & 3320 & 3156 & 2945 & $1705_{\mathrm{sh}}$ & 1494 & ---- \\
\hline$\left[\mathrm{Cu}(\mathrm{L}) \mathrm{Cl}_{2}\right]$ & - & 3487 & 3209 & 3114 & 1689 & 1602 & 430 \\
\hline$\left[\mathrm{Co}(\mathrm{L})_{2}\left(\mathrm{H}_{2} \mathrm{O}\right) \mathrm{Cl}\right] \mathrm{Cl}$ & - & 3467 & 3370 & 3330 & 1650 & 1550 & 453 \\
\hline$\left[\mathrm{Cu}(\mathrm{L})_{3}\right] \mathrm{Cl}_{2} \cdot 1 / 2 \mathrm{EtOH}$ & 3444 & 3410 & 3194 & & - & 1642 & 435 \\
\hline$\left[\mathrm{Co}(\mathrm{L})_{3}\right] \mathrm{Cl}_{2}$ & - & 3447 & 3200 & 3055 & 1669 & 1628 & 440 \\
\hline$\left[\mathrm{Cu}(\mathrm{L}) \mathrm{I}_{2}\right] \cdot 2 \mathrm{H}_{2} \mathrm{O}$ & 3445 & 3411 & 3278 & & - & 1661 & 429 \\
\hline$\left[\mathrm{Co}(\mathrm{L})\left(\mathrm{H}_{2} \mathrm{O}\right)_{2} \mathrm{I}_{2}\right]$ & - & 3435 & 3320 & 3090 & 1660 & 1615 & 435 \\
\hline$\left[\mathrm{Co}(\mathrm{L})_{3}\right] \mathrm{I}_{2} \cdot 1 / 2 \mathrm{EtOH} \cdot 2 \mathrm{H}_{2} \mathrm{O}$ & 3450 & 3420 & 3365 & 3130 & 1675 & 1620 & 425 \\
\hline$\left[\mathrm{Cu}(\mathrm{L})_{3}\right] \mathrm{I}_{2}$ & - & 3410 & 3320 & 3110 & 1660 & 1610 & 440 \\
\hline
\end{tabular}



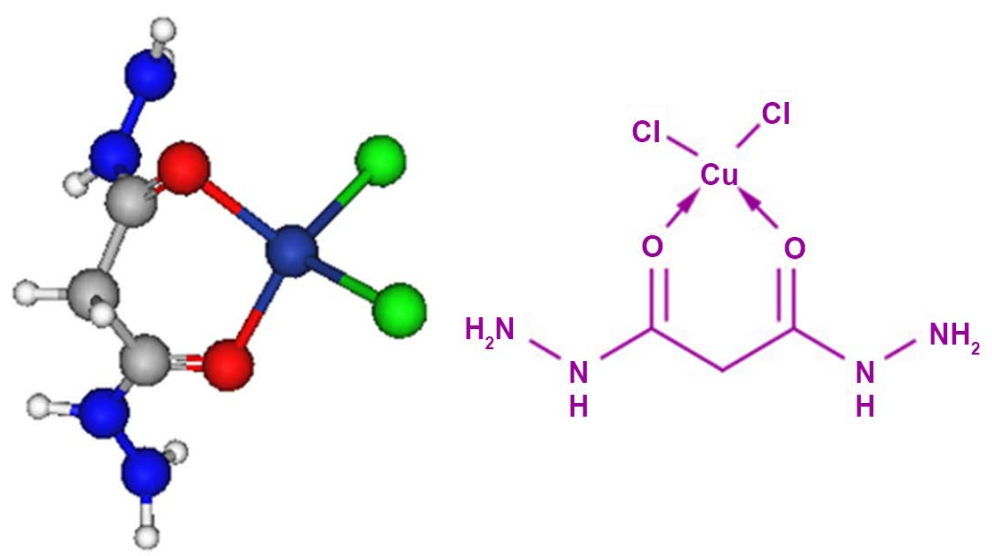

Figure 4. Structure of $\left[\mathrm{Cu}(\mathrm{L}) \mathrm{Cl}_{2}\right]$.
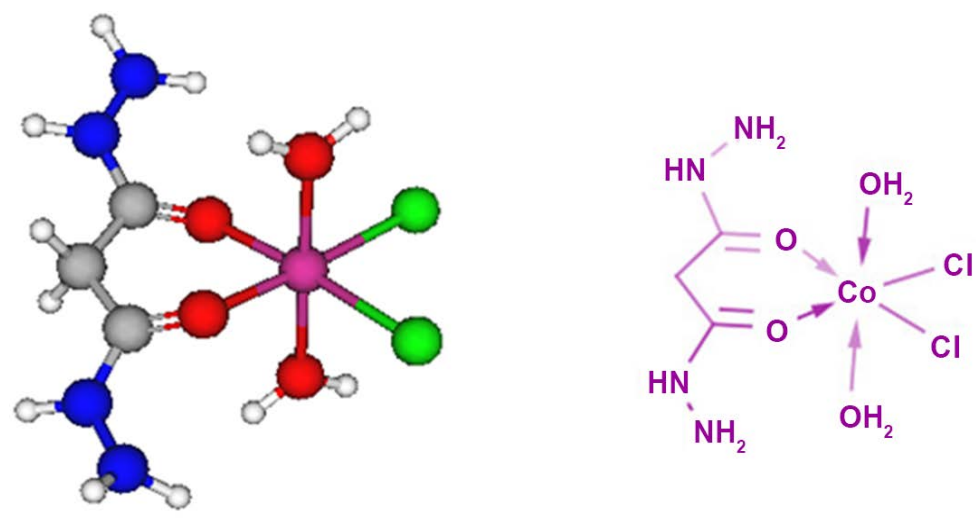

Figure 5. Structure of $\left[\mathrm{Co}(\mathrm{L})\left(\mathrm{H}_{2} \mathrm{O}\right)_{2} \mathrm{Cl}_{2}\right]$.
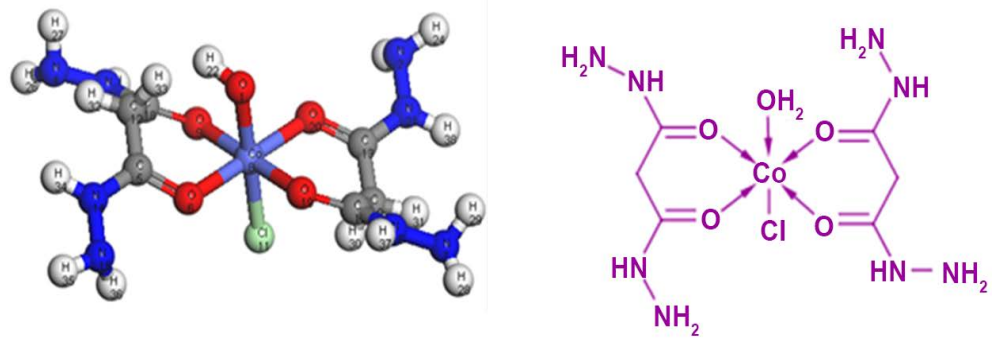

Figure 6. Structure of $\left[\mathrm{Co}(\mathrm{L})_{2}\left(\mathrm{H}_{2} \mathrm{O}\right) \mathrm{Cl}\right] \mathrm{Cl}$.
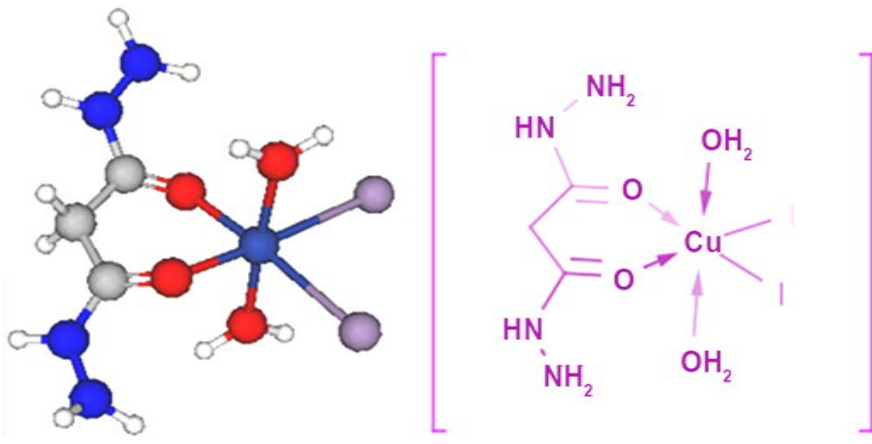

$\mathrm{XH}_{2} \mathrm{O}$

Figure 7. Structure of $\left[\mathrm{Cu}(\mathrm{L})\left(\mathrm{H}_{2} \mathrm{O}\right)_{2} \mathrm{I}_{2}\right]$. 

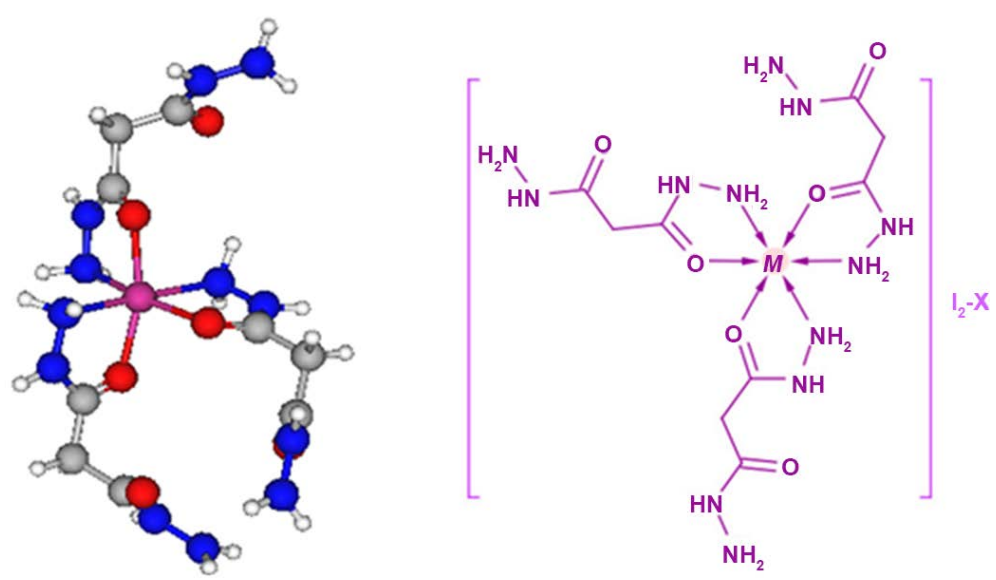

Figure 8. $\left[\mathrm{Cu}(\mathrm{L})_{3}\right] \mathrm{I}_{2}(\mathrm{X}=\mathrm{O})$ and $\left[\mathrm{Co}(\mathrm{L})_{3}\right] \mathrm{I}_{2} \cdot 1 / 2 \mathrm{EtOH} \cdot 2 \mathrm{H}_{2} \mathrm{O}$.

no oxidation of $\mathrm{Co}^{2+}$ to $\mathrm{Co}^{3+}$ ion as reported earlier by Mostafa et al. [21]. The electronic spectrum of $\left[\mathrm{Co}(\mathrm{L})_{2} \mathrm{Cl}_{2}\right] \mathrm{Cl}$ in Nujol mull shows three bands in the $15,700,19,840$ and $21,740-28,900 \mathrm{~cm}^{-1}$ regions attributed to the ${ }^{3} \mathrm{~T}_{1 \mathrm{~g}} \rightarrow{ }^{3} \mathrm{~T}_{2 \mathrm{gg}}{ }^{3} \mathrm{~T}_{1 \mathrm{~g}}$ $\rightarrow{ }^{3} \mathrm{~A}_{2 \mathrm{~g}}$ and ${ }^{3} \mathrm{~T}_{\mathrm{gg}} \rightarrow{ }^{3} \mathrm{~T}_{1 \mathrm{~g}}$ transitions, respectively, in a high-spin octahedral $\mathrm{Co}^{2+}$ system. The observation of these three bands may also suggest that the complexes have trans-configuration [22] [23]. All the above foundations suggest representative structures for the isolated complexes with the general formulae, $\left[\mathrm{Cu}(\mathrm{L}) \mathrm{Cl}_{2}\right], \quad\left[\mathrm{Co}(\mathrm{L})\left(\mathrm{H}_{2} \mathrm{O}\right)_{2} \mathrm{Cl}_{2}\right], \quad\left[\mathrm{Co}(\mathrm{L})_{2}\left(\mathrm{H}_{2} \mathrm{O}\right) \mathrm{Cl}\right] \mathrm{Cl}, \quad\left[\mathrm{Cu}(\mathrm{L})\left(\mathrm{H}_{2} \mathrm{O}\right)_{2} \mathrm{I}_{2}\right] \quad$ and $\left[\mathrm{M}(\mathrm{L})_{3}\right] \mathrm{I}_{2} \cdot \mathrm{X}\left(\mathrm{M}=\mathrm{Cu}^{2+}\right.$ or $\mathrm{Co}^{2+} ; \mathrm{X}=\mathrm{O}$ in case for $\mathrm{Cu}^{2+}$ and $\mathrm{X}=1 / 2 \mathrm{EtOH} \cdot 2 \mathrm{H}_{2} \mathrm{O}$ in case of $\mathrm{Co}^{2+}$ are shown in Figures 4-8, respectively.

\section{Conclusion}

In continuation of our earlier work on tribochemical reactions and the role of metal ions as well as the ligand used in reduction of $\mathrm{Cu}^{2+}$ and oxidation of $\mathrm{Co}^{2+}$, we extend our work to include malonic acid dihydrazide $(\mathrm{L})$ with $\mathrm{Cu}^{2+}$ and $\mathrm{Co}^{2+}$ by chemical and tribochemical reactions. The ligand coordinates in a bidentate manner towards the metal ions. Also, the results indicate the substitution of the chloride by iodide ions has occurred in $\mathrm{Cu}^{2+}$ and $\mathrm{Co}^{2+}$ complexes. Moreover, the reduction of $\mathrm{Cu}^{2+}$ to $\mathrm{Cu}^{+}$and the oxidation of $\mathrm{Co}^{2+}$ to $\mathrm{Co}^{3+}$ have not been occurred and confirmed by chemical, spectral and magnetic measurements.

\section{References}

[1] Prakash, G., Vinod, K.C.H. and Sangamesh, A.P. (2009) Synthesis, Spectral Characterization, in-Vitrmicrobiological Evaluation and Cytotoxic Activities of Novel Macrocyclicbis-Hydrazone. Medicinal Chemistry, 2, 1-8.

[2] Kriza, A., Ababel, L.V. and Cioatera, N. (2010) Synthesis and Structural Studies of Complexes of $\mathrm{Cu}, \mathrm{Co}, \mathrm{Ni}$ and $\mathrm{Zn}$ with Isonicotinic Acid Hydrazide and Isonicotinic Acid (1-NaphthylMethylene) Hydrazide. Journal of the Serbian Chemical Society, 75, 229-242. https://doi.org/10.2298/JSC1002229K

[3] Sondhi, S. Dinodia, M. and Kumar, A. (2006) Synthesis, Anti-Inflammatory and Analgesic Activity Evaluation of some Amidine and Hydrazone Derivatives. Bioor- 
ganic \& Medicinal Chemistry, 14, 4657-4663.

https://doi.org/10.1016/j.bmc.2006.02.014

[4] Bredihhin, A., Groth, U.M. and Mäeorg, U. (2007) Formation and Use of a Nitrogen Dianion for Selective Hydrazine Alkylation Provides a Fast and Easy Access to Substituted Hydrazines, Which Are Widely Used As Drugs, Pesticides, and Precursors for a Variety of Compounds in Organic Synthesis. Organic Letters, 9, 1097-1099. https://doi.org/10.1021/ol070026w

[5] Tšubrik, O., Sillard, R. and Mäeorg, U. (2006) Excellent Regioselectivity Is Observed in the Addition of Diverse Organometallic Nucleophiles to Unsymmetrical AzoCompounds. Primary/Secondary/Tertiary Alkyl, Aryl and Heteroaryl Substituents Were Introduced This Way in High Yields. Synthesis, 5, 843-846.

[6] Bredihhin, A. and Mäeorg, U. (2007) Alkylation of Hydrazine Using a Polyanion Strategy Provides a Fast and Convenient Access to Multialkylated Hydrazine Derivatives. Scope and Limitations of the New Method Are Also Investigated. Organic Letters, 9, 4975-4977. https://doi.org/10.1021/ol702234s

[7] Kucukguzel, S.G., Mazi, A., Sahin, F., Ozturk, S. and Stables, J. (2003) Synthesis and Biological Activities of Diflunisal Hydrazide-Hydrazones. European Journal of Medicinal Chemistry, 38, 1005-1013. https://doi.org/10.1016/j.ejmech.2003.08.004

[8] Narang, R., Narasimhan, B. and Sharma, S. (2012) A Review on Biological Activities and Chemical Synthesis of Hydrazide Derivatives. Current Medicinal Chemistry, 19, 569-612. https://doi.org/10.2174/092986712798918789

[9] Susan, M.A., Marc, O., David, P. and Ann, M. (2003) Mechanism of Horseradish Peroxidase Inactivation by Benzhydrazide: A Critical Evaluation of Arylhydrazidesas Peroxidase Inhibitors. Biochemical Journal, 375, 613-621. https://doi.org/10.1042/bj20021936

[10] Bredihhin, A., Groth, U.M. and Mäeorg, U. (2007) Formation and Use of a Nitrogen Dianion for Selective Hydrazine Alkylation Provides a Fast and Easy Access to Substituted Hydrazines, Which Are Widely Used as Drugs, Pesticides and Precursors for a Variety of Compounds in Organic Synthesis. Organic Letters, 9, 1097-1099. https://doi.org/10.1021/ol070026w

[11] Bredihhin, A. and Mäeorg, U. (2007) Alkylation of Hydrazine using a PolyanionStrategy Provides a Fast and Convenient Access to Multialkylated Hydrazine Derivatives. Scope and Limitations of the New Method Are Also Investigated. Organic Letters, 9, 4975-4977. https://doi.org/10.1021/ol702234s

[12] Singh, P., Goel, R.L. and Singh, B.P. (1975) Synthesis, Characterization and Biological Activity of Schiff Bases. Journal of the Indian Chemical Society, 52, 958-959.

[13] Mahindra, A.M. and Fisher, J.M. (1983) Rabinovitz. Bathocuproine Sulphonate: A Tissue Culture-Compatible Indicator of Copper-Mediated Toxicity. Nature (London), 303, 64-69. https://doi.org/10.1038/303064a 0

[14] Berkessel, A., Bolte, M.T. and Nemann, L.S. (1996) Synthesis and X-Ray Crystal Structure of the First Mononuclear Nickel(II) Alkane Thiolate Complex with a Mixed (S,N,N,O) Ligand Field. Chemische Berichte, 129, 1183-1189. https://doi.org/10.1002/cber.19961291007

[15] Kolodziej, A.F. (1994) The Chemistry of Nickel-Containing Enzymes. Progress in Inorganic Chemistry, 41, 493-495.

[16] Aggarwal, R.C. and Singh, B. (1976) Synthesis and Structural Studies of Simple and Mixed Acid Dihydrazide Complexes of Oxovanadium (IV). Transition Metal Chemistry, 1, 161-166. 
[17] Ahmed, A.D., Mandal, P.K. and Chaaudhuri, N.R. (1966) Metal Complexes of Malonic Dihydrazide. Journal of Inorganic and Nuclear Chemistry, 28, 2951-2959. https://doi.org/10.1016/0022-1902(66)80022-2

[18] Vogel, A.I. (1961) A Text Book of Quantitative Inorganic Chemistry. Longmans, London.

[19] Lewis, L. and Wilkins, R.G. (1960) Modern Coordination Chemistry. Interscience, New York.

[20] Geary, W.J. (1971) The Use of Conductivity Measurements in Organic Solvents for the Characterisation of Coordination Compounds. Coordination Chemistry Reviews, 7, 81-122. https://doi.org/10.1016/S0010-8545(00)80009-0

[21] Al-Ashqar, S.M. and Mostafa, M.M. (2008) Synthesis of Some Novel Co ${ }^{\mathrm{II}}$ and Co ${ }^{\mathrm{III}}$ Complexes by Tribochemical Reactions using KI with Some Derivatives of Thiosemicarbazide Complexes Derived from Girard's T and P. Spectrochimica Acta, 71, 1321-1326. https://doi.org/10.1016/j.saa.2008.04.003

[22] Burger, K., Ruff, I. and Ruff, F. (1965) Some Theoretical and Practical Problems in the Use of Organic Reagents in Chemical Analysis-IV Infrared and Ultraviolet Spectrophotometric Study of the Dimethylglyoxime Complexes of the Transition Metals. Journal of Inorganic and Nuclear Chemistry, 27, 179-190. https://doi.org/10.1016/0022-1902(65)80208-1

[23] Lever, A.B.P. (1984) Inorganic Electronic Spectroscopy. Elsevier, Amsterdam. 


\section{Supplementary}

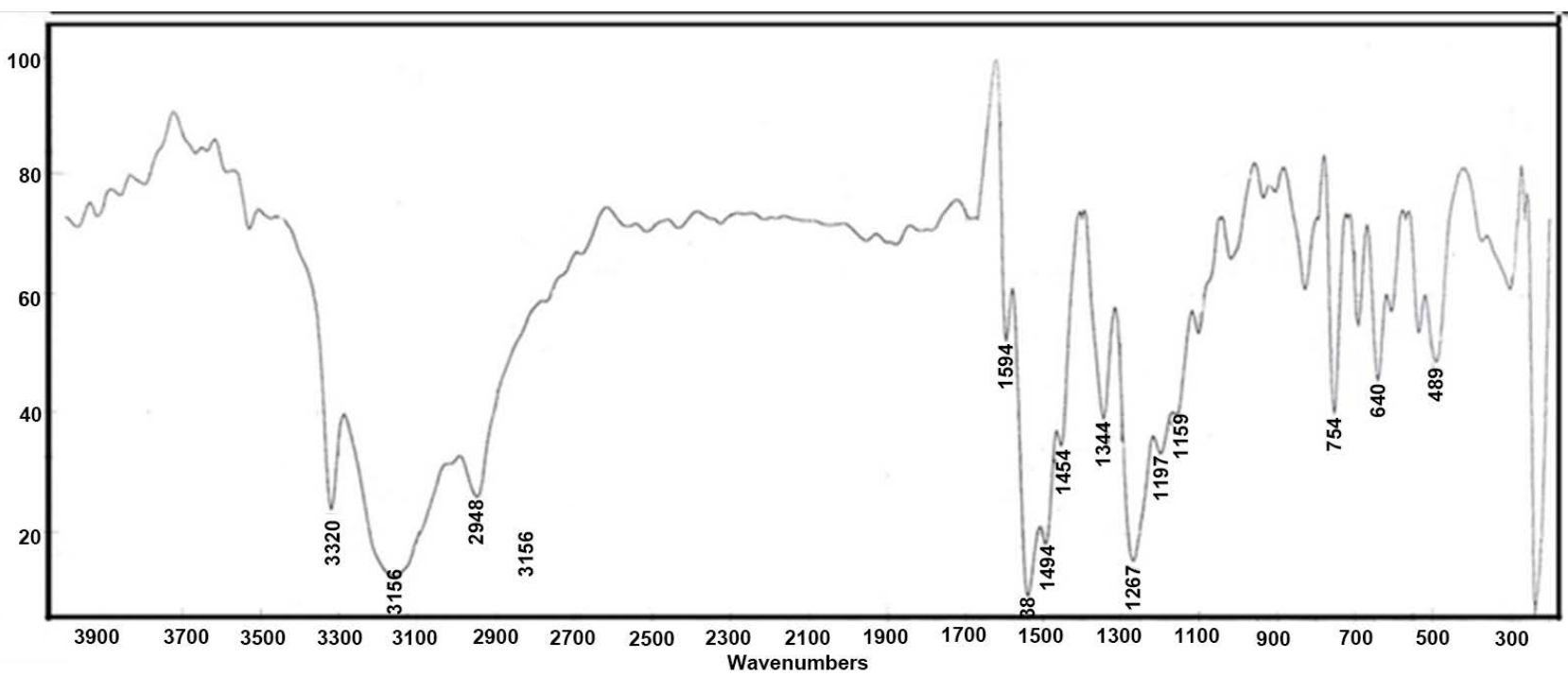

Figure S1. IR spectrum of $\mathrm{L}$ in $\mathrm{KBr}$.

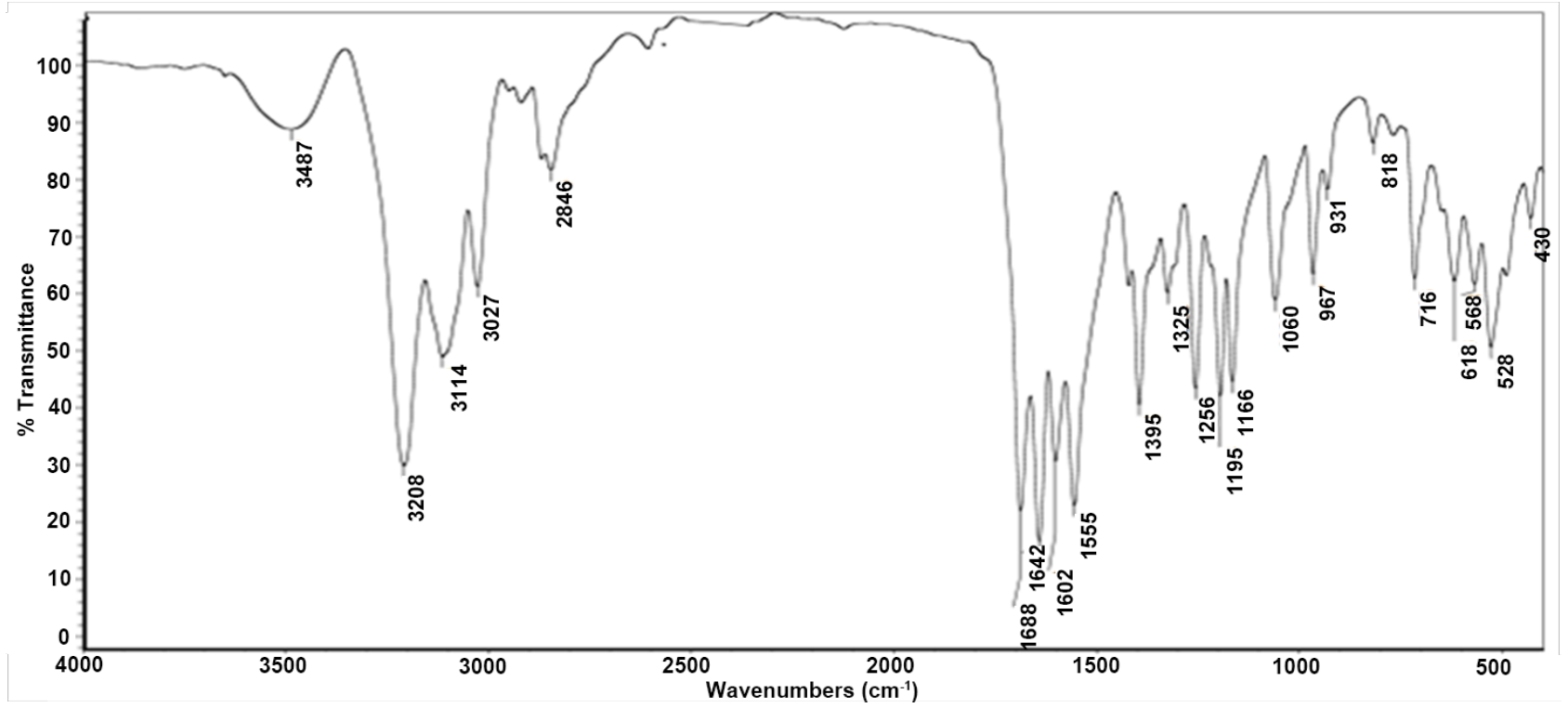

Figure S2. IR spectrum of $\left[\mathrm{Cu}(\mathrm{L}) \mathrm{Cl}_{2}\right]$ in $\mathrm{KBr}$. 


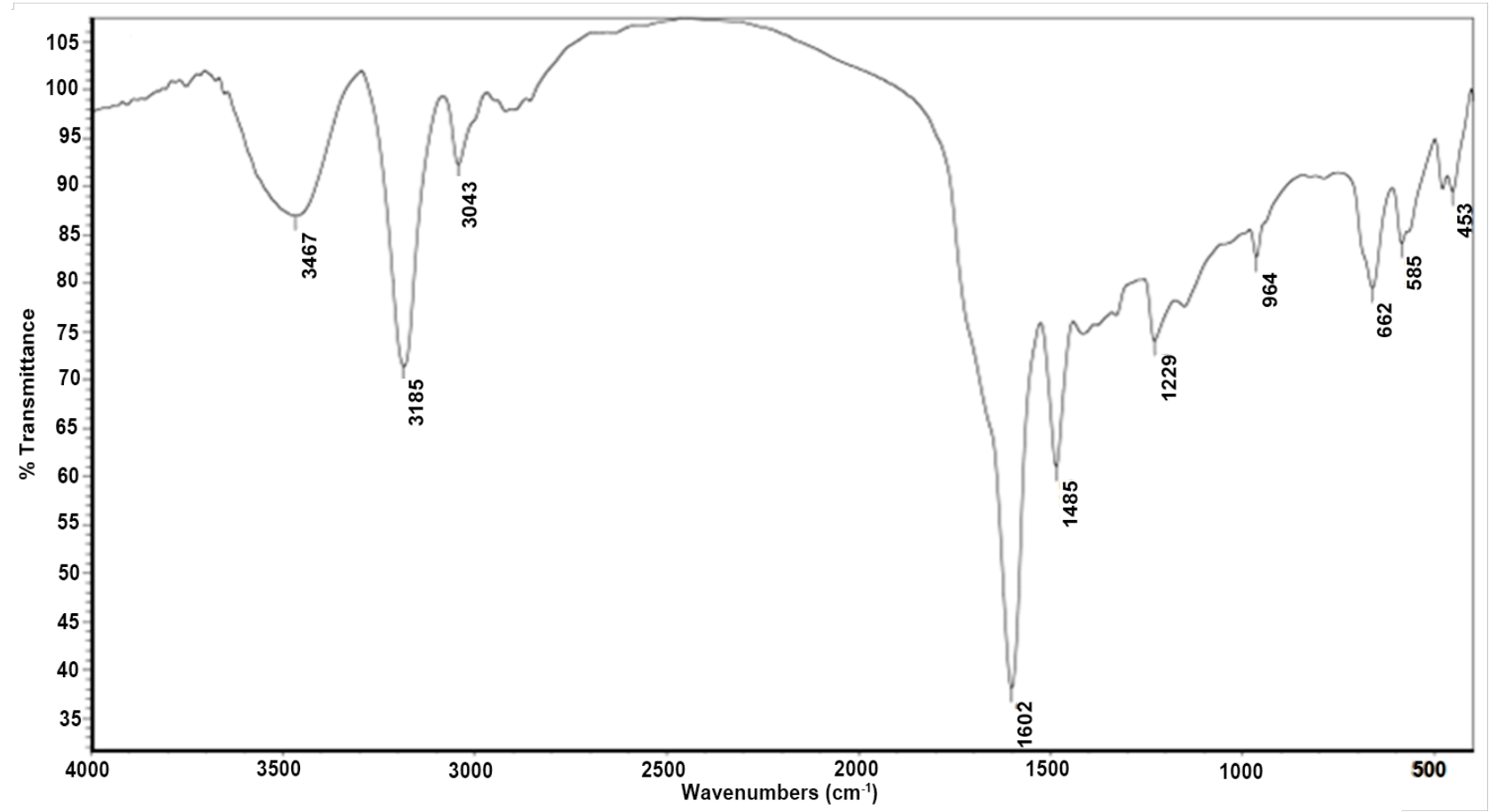

Figure S3. IR spectrum of $\left[\mathrm{Co}(\mathrm{L})_{2}\left(\mathrm{H}_{2} \mathrm{O}\right) \mathrm{Cl}\right] \mathrm{Cl}$ in $\mathrm{KBr}$.

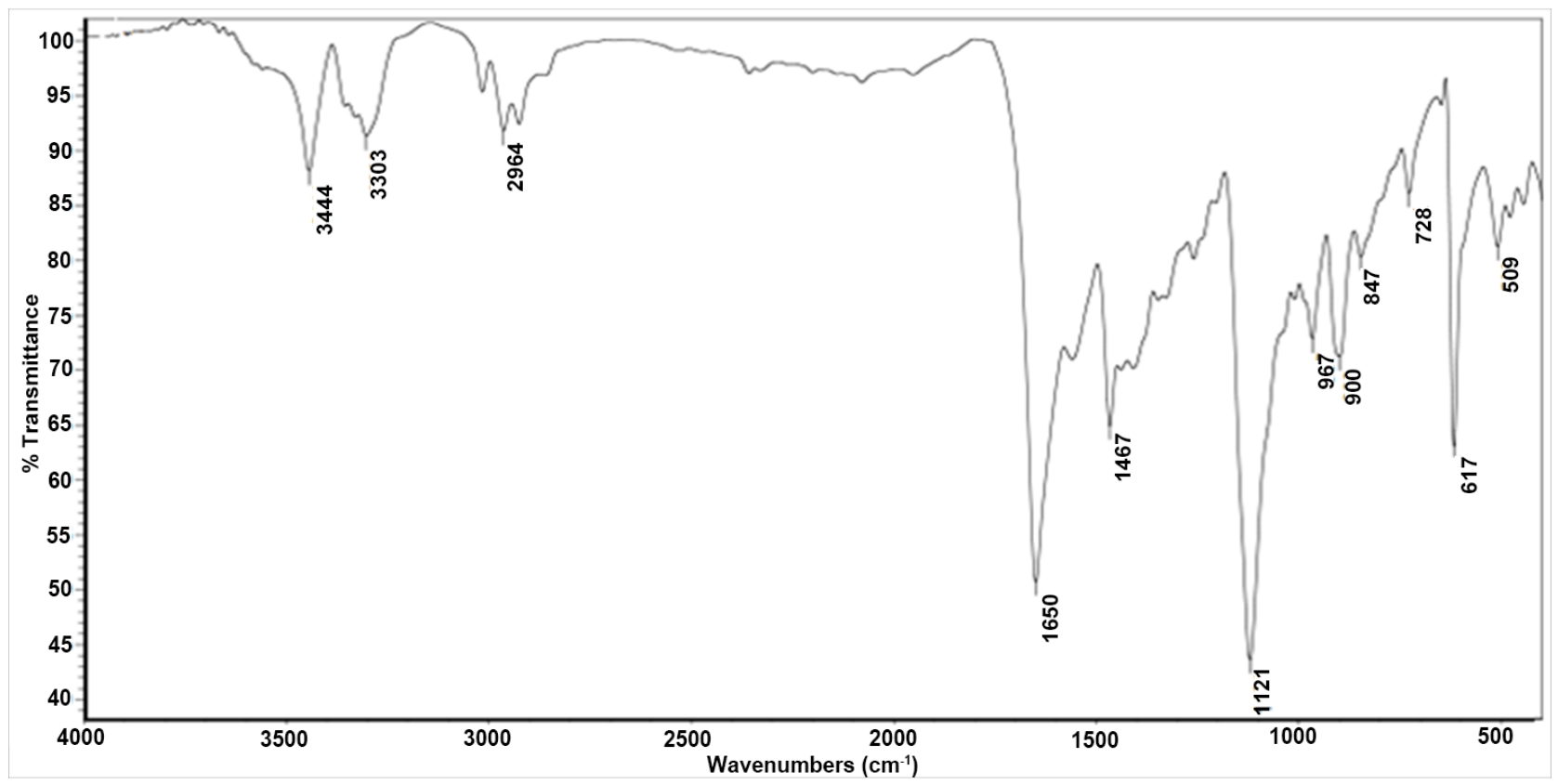

Figure S4. IR spectrum of $\left[\mathrm{Cu}(\mathrm{L})_{3}\right] \mathrm{Cl}_{2} \cdot \frac{1}{1} \cdot 2 \mathrm{EtOH}$ in $\mathrm{KBr}$. 


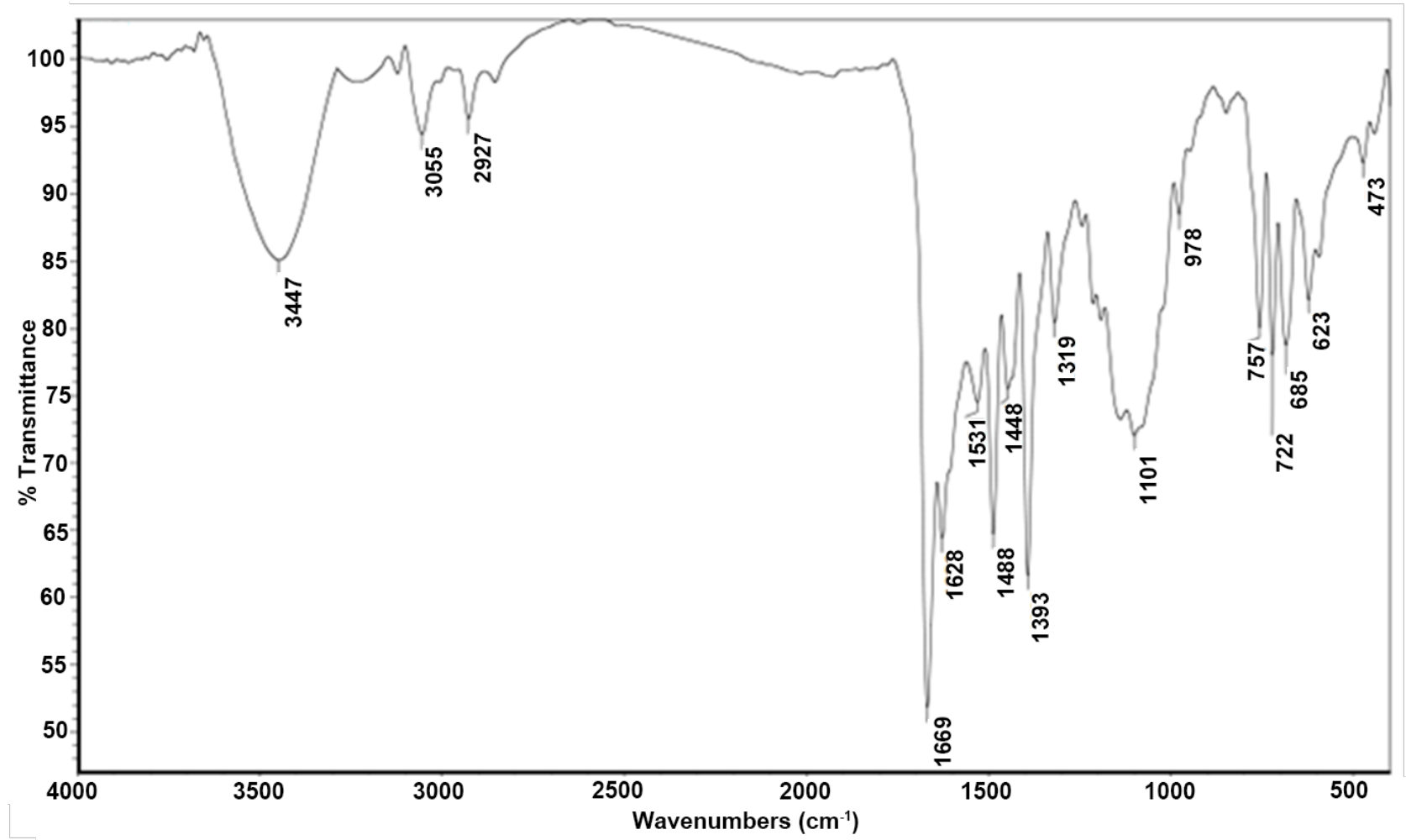

Figure S5. IR spectrum of $\left[\mathrm{Co}(\mathrm{L})_{3}\right] \mathrm{Cl}_{2}$ in $\mathrm{KBr}$.

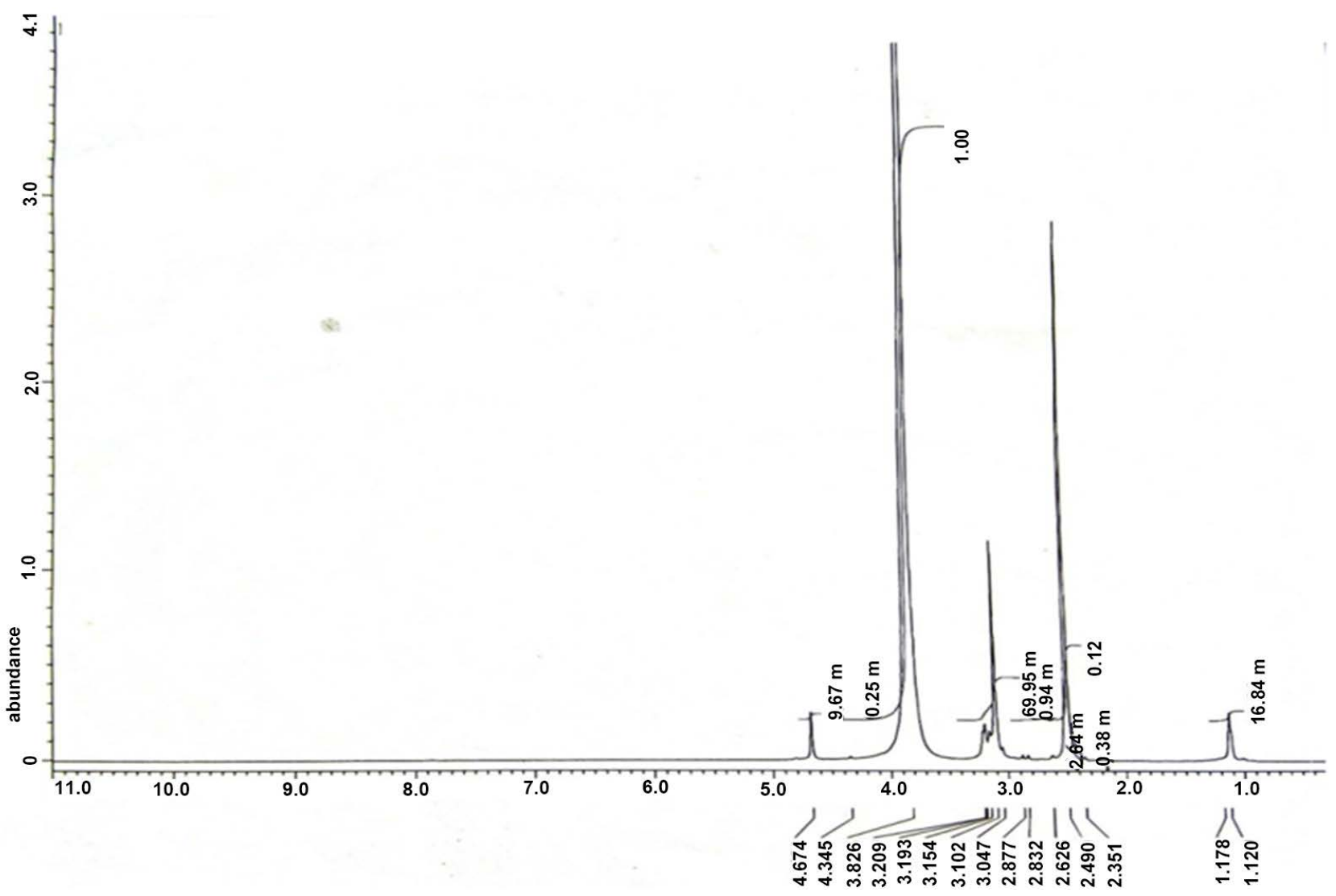

Figure S6. ${ }^{1} \mathrm{H}-\mathrm{NMR}$ spectrum of $\mathrm{L}$ in $\mathrm{d}_{6}$-DMSO and $\mathrm{D}_{2} \mathrm{O}$. 


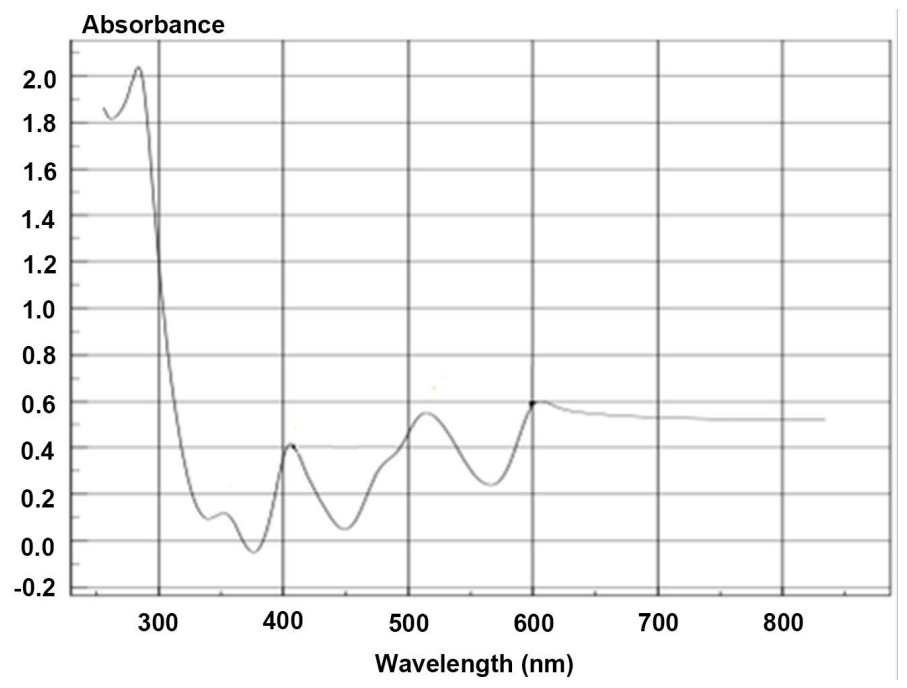

Figure S7. UV spectrum of $\left[\mathrm{Cu}(\mathrm{L}) \mathrm{Cl}_{2}\right]$ in Nujol.

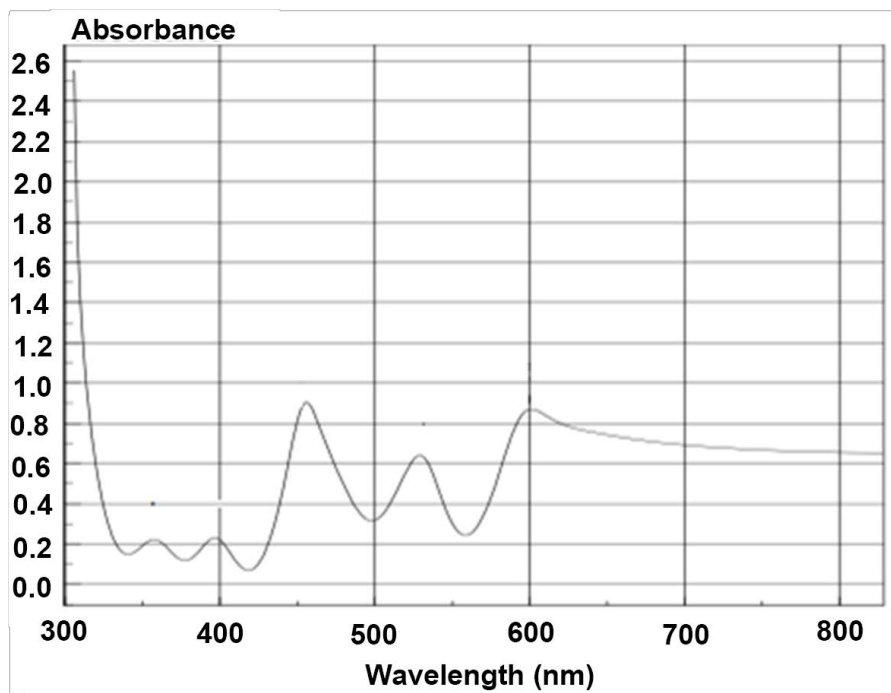

Figure S8. UV spectrum of $\left[\mathrm{Co}(\mathrm{L})_{2}\left(\mathrm{H}_{2} \mathrm{O}\right) \mathrm{Cl}\right] \mathrm{ClinNujol}$.

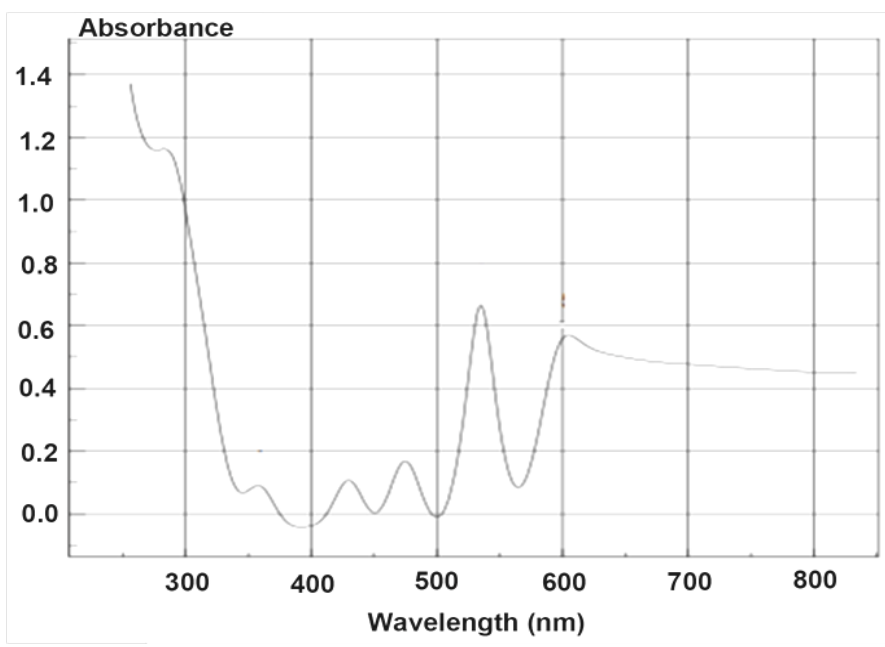

Figure S9. UV spectrum of $\left[\mathrm{Cu}(\mathrm{L})_{3}\right] \mathrm{Cl}_{2} \cdot 1 / 2 \mathrm{EtOH}$ in Nujol. 


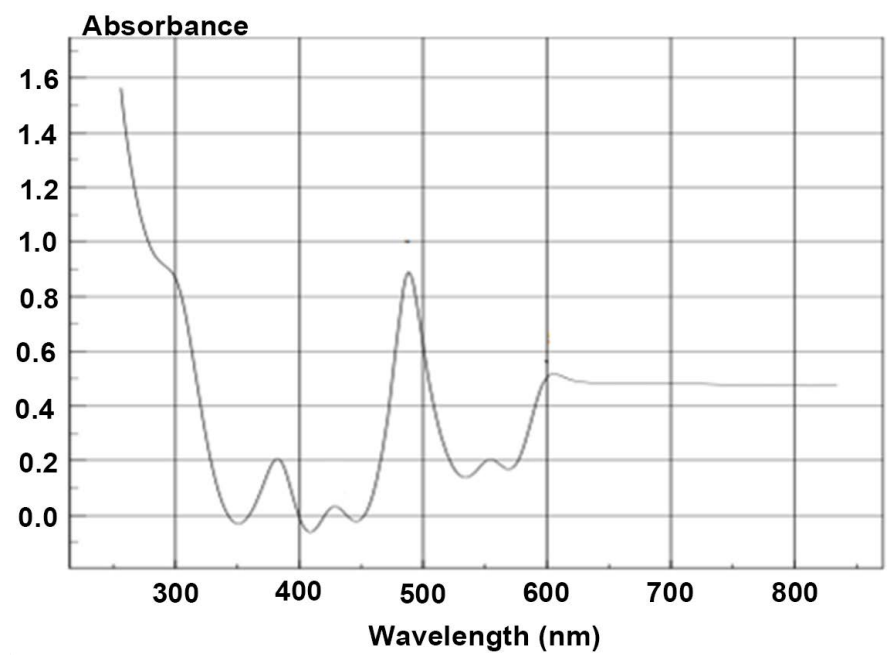

Figure S10. UV spectrum of $\left[\mathrm{Co}(\mathrm{L})_{3}\right] \mathrm{Cl}_{2}$ in Nujol. 